\title{
COMPETITION LAW PROVISIONS APPLIED IN SPORTS. ARTICLES 101 AND 102 TFEU (PART I) ${ }^{1}$
}

\author{
DOl:10.24193/SUBBiur.62(2017).1.5 \\ Published Online: 2017-03-15 \\ Published Print: 2017-03-30
}

\section{Daniela-Olivia GHICAJANU*}

Abstract: Competition law provisions tend to be used by both the European and National competent authorities on different markets. The sports market is one of the newest and brings many novelties. Sportsmen in Europe perform also economic activities which created a whole new industry. This article will be focused on the possibilities and modalities to apply Article 101 TFEU.

Keywords: competition law, sports industry, sports law, market, Article 101 TFEU, European Commission, ECJ.

\section{Introduction}

1. Sports represent a typical human activity, but with a different approach from a simple competition to a business area. Nevertheless, this field has also an economic dimension shall be analysed from a legal and financial points of view.

2. The idea of an economic activity which needs to be regulated is not new, but it is, still, raising lots of debates. Only professional sports are an economic activities. Professional sport is regulated by legal and technical norms. These last ones are also known as lex sportiva; soft law created by the sports regulating bodies and the jurisprudence of CAS/TAS.

3. In Europe, the debates around qualification of sports' activities begun in 1974 when the European Court of Justice (hereandafter ECJ) had to give its judgement regarding the conformity of national clauses with the European law [Art. 45 from the Treaty for Functioning of the European Union - TFEU - (ex -39 TCE)].

In the two cases analysed at that time, Dona ${ }^{2}$ and Walrave ${ }^{3}$, it was for the first time when the ECJ had to reason whether European law applies or not to sports activities. The General Advocate in his conclusions proposed the application of one of the four fundamental freedoms. The Court tried to avoid a decision too narrow which could undermine the authority 
of the European and International Sport Federations. So, in these two cases the ECJ concluded that European law applies to sports' activities only when it has an economic dimension. In this situation, the nationality clauses do not relate with an economic aspect, but merely with sports organization system which means that European law shall not be applied.

4. After two decades of total silence, the ECJ had, again, to analyse if the European law provisions can be applied in case of players' transfers when clubs are located in different Member States. This was the revolutionary decision in case Bosman ${ }^{4}$.

The ECJ stated that " 1 . Article 48 of the EEC Treaty precludes the application of rules laid down by sporting associations, under which a professional footballer who is a national of one Member State may not, on the expiry of his contract with a club, be employed by a club of another Member State unless the latter club has paid to the former club a transfer, training or development fee.

2. Article 48 of the EEC Treaty precludes the application of rules laid down by sporting associations under which, in matches in competitions which they organize, football clubs may field only a limited number of professional players who are nationals of other Member States.

3. The direct effect of Article 48 of the EEC Treaty cannot be relied upon in support of claims relating to a fee in respect of transfer, training or development which has already been paid on, or is still payable under an obligation which arose before, the date of this judgment, except by those who have brought court proceedings or raised an equivalent claim under the applicable national law before that date."

5. The Bosman rulling changed the transfer system of footballers. It obliged both UEFA and FIFA to pay close attention to the European law provisions and comply with them. Transfer of players is an economic side of sports, it is one of the most common methods used to finance clubs' activity.

6. In Bosman, the ECJ accepted the solution proposed by the General Advocate Lenz, which was reasoned according to the general principles of law and the past jurisprudence of the Court. An interesting point to be discussed, later in our article, is that the applicant, Mr. Bosman, claimed the application not only of Art. 48 of the Rome Treaty, but also of competition provisions.The ECJ tried to avoid again the matter, even if the General Advocate proposed that competition law shall be applied because the transfer rules were against the Treaty.

7. At the European level, only recently, it was accepted that competition law provisions should be applied to sports industry. This involved mostly the different sources of financing like cessation of media rights, sponsorships agreements or publicity contracts. In the last decade the frequency of European Commission's investigations in sports market raised.

8. The central question of this article to which we will try to answer is "Why should we consider a necessity to apply the competition law provisions in sports?". The sports field is regarded by the European Commission as a growing industry where competition rules shall be applied. Nevertheless, it is mandatory to take into account the sport' specificity. 


\section{Compliance between competition law rules and sports law}

9. Sports field is regarded by the European Commission as a new area of business with a growing economic impact ${ }^{5}$ : the sports business. The new and in constant evolution face of sport tends to become the habit.

10. The ECJ was reluctant to apply competition law to sports as we previously saw. In its first decisions it tried to balance the specificity of sports and its economic side. But since Dona case, there is a clear rule: "when sport is regarded more as an economic activity, European law applies".

11. One of the most popular decisions in the sector was in Bosman and its effects are seen even today. Technically speaking this is not a pure competition law decision because the core of it relies more on Art. 48 of Rome Treaty. But the opinion of Advocate General Lenz regarding the possibility to apply the competition law along with the free movement of persons' rules cannot be ignored.

12. Nevertheless, when sports have an economic nature, also antitrust law applies ${ }^{6}$. This principle can be extracted from Dona ruling. In the Report delivered by the European Commission in 1999 to the European Council in Helsinki, the Commission stated very clear that after Bosman ruling the sports national and international federations shall respect European law, so, including the antitrust law and state aid law. But in the first phase the tendency was to protect the federations and their autonomy by invoking the social, educational and cultural role of sport. Also by stating that without these sports bodies the "game rules" would not exist.

It was not intended to apply competition law to sports in its original shape. But alongside with the professionalization of sport and the raise of entertainment function, it became a true economic sector ${ }^{8}$.

13. In some specific cases ECJ concluded that competition law could be applied also to doping cases $^{9}$. These rules are elaborated by the sporting bodies which may try to avoid competition law saying that sports' specificity needs an exemption ${ }^{10}$. What are trying these sport regulators is to create a universal sports exception in order to avoid EU or national law's application. But this type of general sports exception is not accepted. Thus, is neither justified to have such an exception ${ }^{11}$.

\section{PART I. Article 101 TFEU - Application, conditions and practical exceptions III. Conditions for Article 101 TFUE application in sports industry}

14. Antitrust law is applied by both European and national authorities in order to prevent any dysfunctions on the Internal Market. The main purpose is to protect the market as well as the consumers. This general principle is applied also in the sports sector. 
15. Art. 101(1) TFEU prohibits agreements, decisions by associations of undertakings and concerted practices that are restrictive of competition. Art. 101(3) provides an exception when actually Art. 101(1) becomes inapplicable. If there is an agreement which is against Art. 101(1) and in the same time is not covered by Art. 101(3) then, by virtue of Art. 101(2), the agreement shall be declared null and void ${ }^{12}$.

16. Art. 101(1) explains which are the general and cumulative conditions of an anticompetitive behaviour:

1) Existence of at least two undertakings separated or by association

2) Co-ordination of market behaviour expressed via an agreement, a concerted practice or decision of an association of undertakings

3) The object or effect of such an agreement shall be prevention, distortion or restriction of competition on the market

4) The restriction of competition shall be appreciable (De Minimis Notice)

5) The effect is on the trade between Member States

17. There is no definition of "undertaking or associations of undertakings" in the Treaties. It was ECJ's mission to define them and state the distinction case by case.

The European case-law defines the undertaking as a concept which encompasses every entity engaged in an economic activity regardless of the legal status of the entity and the way in which it is financed ${ }^{13}$. The economic activity was defined next in Pavlov case ${ }^{14}$ as "any activity consisting in offering goods or services on a given market".

In another case, Wouters v. Algemene Raad van de Nederlandsche Orde van Advocaten ${ }^{15}$ the Court ruled that the competition rules in the Treaty do not apply to activity which, by its nature, its aim and the rules to which it is subject does not belong to the sphere of economic activity or which is connected with the exercise of the powers of a public authority.

18. In these decisions the European Court offered some general definitions which shall be applied and interpreted from case to case regarding the facts and the context of each case. But what can we assume is that a club, a federation and even a sportsman ${ }^{16}$, in some cases, can be regarded as an undertaking if they pursue an economic activity ${ }^{17}$.

This was also the European Commission's position regarding the World Football Cup in 1990: FIFA, the Italian Football Federation and the National Organizing Committee are undertakings ${ }^{18}$. In its decision regarding distribution of touristic fees for the World Cup, the Commission stated that "it is an economic activity, every activity which participates in economic exchanges, abstraction made by the profit seeker". The conclusion was the same in 1998 regarding the French National Organizing Committee of the World Football Cup ${ }^{19}$.

19. Football clubs are also considered undertakings according to the ECJ decision in Bosman. In this judgment, the Court dismissed the Belgian Football Federation's arguments that only the big European clubs shall be considered as undertakings whether the small clubs shall be regarded as having only insignificant economic activity. Not the European or national dimension is the determinant, but the type of activity. 
20. The legal doctrine in its attempt to align sports law with the EU Competition law concluded that there exists the concept of sport's undertaking or association of undertakings. In this concept are included national, European and International federations, sports clubs and even athletes when they perform an economic activity. In other words, when these entities sell tickets to sport events, rent spaces of the stadiums for publicity, sign publicity contracts or sponsorship agreements, they have a duty to comply with EU Competition law ${ }^{20}$.

21. The evolutionary character of ECJ jurisprudence proved itself in Deliège decision when the Court admitted that even an athlete is an undertaking according to Article 2 from the Treaty when his principal financing resources are a result of publicity contracts ${ }^{21}$. In other words, in such a case the athlete concluded a services contract with the sponsor.

22. There is another important issue when both national and European authorities try to determine the application of competition regulatory: the problem of the relevant (product) market. This market is regarded from two points of view: geographical and products $^{22}$. But the legal doctrine ${ }^{23}$ concluded that in the field of sports, every event is in itself a separated market ${ }^{24}$.

23. Actually, in sports there are two markets interconnected: one is represented by the economic competition generated by the sport event taking place (the sports representation market) and the other is the game market (the sports' activity performed by professional athletes). So, there are economic competition and sports competition as such. One cannot exist without the other.

24. Some differences between these two markets shall be pointed out: the score's incertitude is the main feature of the second market while in the case of the first market every market player has as main goal to reduce the market proportion of its competitors, the second market exists because of the competitors and every player needs its competitor to survive both as a sport entity and performer while the first market can exist even if there is only one major player.

The first market is the typical market where competition law rules apply; while the second one needs a certain degree of attention. There the sport bodies regulating the existence of the competition itself and clubs by establishing some internal rules such as the competition access and financing rules. In these two areas the competition authorities analyse the application of competition law rules.

25. The next step is to analyse if there exists any type of coordination on the market between the sports undertakings. This coordination has many forms expressed also in Art. 101(1) TFUE: agreements, concerted practices or decisions of an association of undertakings.

Between these three types we can extract a common factor: the autonomy of will which drives the undertakings to establish certain behaviour on the market. The coordination can be expressed via a written agreement ${ }^{25}$, an oral one, coordination or a decision of an 
association of undertakings which in the end is the equivalent of a mandate given by the clubs to their federation.

The practical issues arising from the conclusion of an agreement are usually seen in media rights and sponsorships contracts.

26. The coordination by a decision of an association of undertakings can take different forms such as:

1. Regulations issued by the association - this was the case in Bosman ruling where only the General Advocate gave some arguments why the nationality clauses can be considered a decision of an association of undertakings with no importance of the form of collaboration.

2. Agreements between the national federations ${ }^{26}$ - according to UEFA's rules on the retransmission of sport events if there is a game played in other Member States then the federation which is organising has to ask for the permission of the other federation to allow the broadcasting companies to transmit the game ${ }^{27}$.

3. Agreements between television channels - at the European level exists an association of the television channels called the European Union of Radiodiffusion. Its decisions were considered against EU Competition law by the General Court ${ }^{28}$.

27. The next condition refers to the object or effect of these market behaviours of the sports undertakings: prevention, distortion or restriction of competition. It depends from case to case. And as the literature and case law proved, it has to be analysed from an economic point of view.

In a decision of reference ${ }^{29}$, the ECJ stated that in order to decide if an agreement hinders competition by its object "regard must be had inter alia to the content of its provisions, the objectives it seeks to attain and the economic and legal context of which it forms part". And in T-Mobile Netherlands ${ }^{30}$ concluded that if it has only the potential to affect the competition then the agreement is prohibited by Art.101(1) TFEU.

The object has to be regarded from a pragmatic point of view. In this case, the facts and the whole background shall be analysed. This rule is followed by the Commission and the ECJ in every competition case. It was also analysed in the tickets and media rights selling cases investigated by the Commission.

While the object of an agreement can be analysed from the factual and economic point of view, there is a difficulty for the European authorities when it comes to the anticompetitive effect. This is a broad concept which needs a deep and extensive analysis. Moreover, the Commission needs a much longer period of time to foresee the effects on the market and over the consumers. As the European judicature it pointed out in Wouters $^{31}$ and for sports in Meca Medina ${ }^{32}$ - "specific rules cannot be declared as anticompetitive from the beginning but must be analysed if there exists an anti-competitive effect and how a certain domain is organised, in this case the legal profession in a specific country or the access to a sport competition. They must be put in balance and if the objectives are non-competition but the effects restrict the competition it may appear that the objectives are more important on the long term." 
28. The last condition is that the trade between at least two Member States must be affected. But this one is envisaged only when the European Commission starts an investigation. If there is a national case, the competition authority has to see if the trade in general is affected or not. Again, the economic side is firstly regarded. This condition depends from case to case.

29. As a conclusion, in order to apply Art. 101(1) TFEU to sports activities the conditions are the same as for any other competition investigation. The difference is that in sports activities the competition authorities must take into account the "sports' specificity" claimed so often by the sports bodies. In case of the specificity of sports, Art. 101 (3) TFEU is applicable and though the practice is exempted from sanction.

In the following lines we will address the practical issues of Art. 101 TFEU.

\section{A. Media rights selling and European Competition Law}

30. Financing the sports sector has its difficulties. One source to finance sport is to commercialize it. The most used commercialization of professional sports is the media rights selling by the organizers of sports competitions to media companies. Buying and selling sports media rights emerged really fast in the mid of the '90s and the beginning of 2000s. Certainly, this commercialization is an economic activity which reveals the necessity to apply competition law provisions.

\section{Importance of media rights selling in sport}

31. This marriage between sport and television is one made in heaven (Goldlust 1987). It is a self-interest and dependence relationship. Both industries achieve valuable economic benefits from this partnership: sports provide valuable content and audience for media companies, while the media is a source of revenue ${ }^{33}$. The question is how, from a legal point of view, it can be established a relationship between the two industries? To answer this question we shall see how the professional sports activities exist.

32. Firstly, there is a club which register itself to a federation as a professional club. After, it starts to employ professional sportsmen, to participate in professional competitions. Its revenue sources are most of the times: shareholders' investments, donations and commercial contracts.

33. The foundation of a sports activities-media trust relationship is the conclusion of a contract. The agreement is concluded between the club/the competition organizer ${ }^{34}$ of the competition and the media undertaking. The organizer holds the image rights over the competition. These rights include also the rights to broadcast the competition. The organizer agrees to cessation of the right to a media company because it does not have the infrastructure or the necessary qualifications to publicly promote and transmit the competition. 
Legally, these two entities concluded a typical selling contract. A sum of money will be distributed after to the club(s), team(s) and athletes. The price of this contract is actually an investment in sports. It is the principle source of revenue for sports activities. In this case the competition authorities have to pay close attention to these contracts because both national and European media rights markets shall be protected.

\section{Analysis of Article's 101 (1) TFEU application in media rights selling}

34. Media rights companies try to exploit the position they have when it comes to media rights acquisitions. Such a behaviour can be encountered when media trusts impose exclusive media rights contracts for long periods of time.

The consequences of such behaviour are foreclosure of the media market. Obviously, it restricts the market and creates dominance of the media undertakings. But the European Commission and National Competition Authorities intervened to set some limits of these practices.

35. The demand for broadcasting rights is constantly increasing and new media technologies are used. So, there are many more challenges for competition law ${ }^{35}$. The cases regarding selling of media rights were investigated by the competition authorities with reference, mainly, to Article 101 (1) TFEU (ex-81 TCE). ${ }^{36}$

36. Article 101(1)'s conditions will be discussed to see how the European Commission applied them to the sports sector.

\section{(i). Undertakings and associations of undertakings}

37. According to the definition offered by ECJ, the concept of "undertaking" was seen "as every entity engaged in economic activity regardless of the legal status of the entity and the way it is financed ${ }^{37 "}$ ". An economic activity encompasses any activity that involves "offering goods or services on the market". Sports clubs and sports regulating bodies are undertakings when they engage in economic activities. Selling media rights is such an activity ${ }^{38}$.

\section{(ii). Agreement, decision, concerted practices}

38. Article 101(1) TFEU uses the terms agreements, decisions of undertakings and concerted practice to refer to a collaborative behaviour of the undertakings implied in an economic activity on a specific relevant market. A simple meeting of the minds is sufficient to have such a collaborative practice. These agreements and decisions might be in a written form, but also are accepted the so called "gentlemen agreements". ECJ stated that an agreement exists when the involved undertakings "have expressed their joint intention to conduct themselves on the market in a specific way"39. 
39. In case of sports events, a selling of media rights might take place via an agreement between the club and a media company, a decision of association, this was the case when UEFA signed the contract for joint selling of media rights" ${ }^{40}$ : "The regulations of the UEFA Champions League provide the regulatory basis for the manner in which the commercial rights of the UEFA Champions League are sold. [...] The Regulations of the UEFA Champions League are binding on the national football associations and on the football clubs".

\section{(iii). The object or effect is prevention, restriction or distortion of competition}

40. This condition allows the competition authorities to appreciate if the undertaking's behaviour on the market affects competition in a negative manner. Whereas for media rights selling as well as for the other industries it can be difficult to distinguish if it was a specific object of the agreement or decision to distort the competition. Also, if the object is not clear, the competition authorities shall analyse all the circumstances and provisions of the contract/ decision or to closely observe the practices of the investigated undertakings on the market.

41. Most of the cases investigated by the Commission or brought before the ECJ had some common features such as: a long period of time for the agreement to be in force, existence of a clause of exclusivity for the media company, exclusive hours to transmit the competition. In a first decision regarding the joint media rights selling, the European Commission pointed that:

"One effect of joint selling, especially when coupled with exclusivity, is that only big media groups can afford the acquisition and exploitation of the bundle of rights. This leads to higher prices and shuts out competitors from key content. Football fans are also potentially harmed since they are offered less football on $T V$, or no coverage at all in those cases where they do not subscribe to pay-TV as there are no live matches on free TV. The lack of competition may also limit the packages of rights available for new media and new technologies, in particular the thirdgeneration of mobile phones, which could see their introduction slowed down as a result. All these anti-competitive effects do not mean, however, that joint selling is to be banned outright. Article 81(3) requires the Commission to assess whether agreements, which at prima facie are anti-competitive could bring benefits, including to the consumer, in which case they could be exempted ${ }^{41 "}$.

The Commission and national authorities will treat each case separately but this condition of the object or effect of the undertakings' behaviour is fundamental to reach out a decision.

\section{(iv). The trade between Member States is affected}

42. This condition is fulfilled most of the times in case of joint media rights selling resulted from a decision of a European or International federation. Its regulations apply within several countries. Interestingly, the European Commission considered that if an agreement is to operate across the territory of an entire Member State this will raise a presumption of effect on interstate trade, as access to this Members State's market may be hampered by this very agreement ${ }^{42}$ 
43. The legal doctrine pointed that not only European and International federation regulations may affect the trade between Member States, but also those issued by a national federation. The conclusion revealed in this case was that agreements concerning national sports events media rights selling can have an effect on the trade between Member States ${ }^{43}$.

\section{(v). Definition of the relevant market}

44. Regarding the definition of the relevant market, usually the Commission defined it as the market of selling or purchasing media rights. But it has to be taken into account that every case has its own specificities. So, the market definition is different from case to case.

There was made a difference between the upstream markets (the markets where the rights owners sell them to media companies) and the downstream markets (the markets where media companies bring the information to the public $\left.{ }^{44}\right)$. The European Commission distinguished the market for television from the other media markets.

45. As to the market of television, the Commission distinguishes again between the pay-television (including pay-per-channel and pay-per-view ${ }^{45}$ ) and the market for free-toair television. In a decision ${ }^{46}$, the European Commission concluded that it may exist two separate markets for analogue and digital television because digital television is only a further development of analogue television. In another case ${ }^{47}$ it recognized the fact that there is a separate market for traditional media and a market for new media, like mobile and Internet rights.

46. The most common markets identified by the European Commission are:

(a) Broadcasting rights for major sports events and broadcasting rights for other television programs ${ }^{48}$.

(b) Broadcasting rights for football games and broadcasting rights for other sports game.

(c) Broadcasting rights for football events played regularly through every year (Champions League, domestic championships etc.) and broadcasting rights for football events that do not take place regularly (Olympic Games, World Cups etc. ${ }^{49}$.

\section{Selling the media rights in sport sector}

47. An important issue which may influence if an agreement falls within or outside the scope of Art. 101(1) TFEU or it can benefit from an exemption, is the act of selling or purchasing those rights.

As we argued before, the entities organizing sports event decide whether they allow the public to see it or not. So, they are the only one to decide the conclusion of an agreement to sell the rights.

48. In Europe, these rights are owned by clubs which previously agreed to transfer them to the Federation or agencies of National Leagues. These entities became the official 
organizers of the event. Meanwhile, they represent the clubs in contracts regarding the commercialization of sport events such as selling of tickets and/or selling of media rights.

49. Within the Internal Market selling of media rights takes many forms, but the most used is the collective selling/buying. This is the "Eurovision", a form of collective selling and buying media rights. One may ask if this falls in the scope of Art. 101 (1) TFEU. The Commission concluded negatively, but the Court of First Instance annulled these decisions ${ }^{50}$.

Further, we will shortly discuss exclusive and collective selling of media rights in sport.

\section{(i). Exclusive selling}

50. Exclusive selling may appear as being in contradiction with Art. 101(1) TFEU. But it is not always the case because there are also other factors to be taken into account, such as the period of time for the exclusivity, the market dimension, the product market and the type of industry. This was the reasoning of the ECJ in its decision Nungesser $v$. Commission ${ }^{51}$ : "the grant of an open exclusive licence, that is to say a licence which does not affect the position of third parties such as parallel importers and licensees for other territories, is not in itself incompatible' with the Treaty".

The Court saw the exclusive selling as an incentive for new competitors to penetrate the market even for a limited period of time. So, all the factual circumstances of an agreement shall be analysed.

51. Regarding the sports field, it was stated that "exclusivity is an accepted commercial practice in the broadcasting sector. It maximises profitability for the buyer and is the key to building up a new audience. But duration, quantity and upstream and downstream market power need to be examined in order to assess whether the exclusivity seriously restricts competition ${ }^{52 \prime \prime}$.

52. In Champions League ${ }^{53}$ case, the Commission distinguished between the market of yearly events and other sports events. In these cases, a contract for a long period of time may fall within the scope of Art. 101(1) TFEU, but not necessarily ${ }^{54}$.

53. As far as now exclusive selling may, at first sight, be considered as against antitrust law, but it is only a first impression. For certainty, it shall be analysed the ECJ's jurisprudence, the situation on the market and the factual circumstances of each case.

\section{Collective selling}

54. Sports clubs cease to federations their media rights. The Federation sells those rights as a whole for one complete season. 
55. One of the most important decisions of the European Commission regarding collective selling of sports media rights concerns the Champions League ${ }^{55}$ investigation, The decision was issued in 2003, when the Commission concluded that the UEFA' system of collective media rights' selling on an exclusive base and for a period of several years infringed Art. 101(1) TFEU (ex-Art. 81 TCE). In its decision the Commission pointed it out that this system was not a set of arrangements that were indispensable to the organisation of sport, but rather it was a commercial choice which affected the competitive process.

56. After this decision, the Commission established some factors to be taken into account when it starts an investigation of broadcasting rights selling. It desires to see that there was an open tender with many buyers, not with an excessive exclusivity (a period of three years or less seems fair) and with no automatic renewal. If these elements exist it is probable to see the agreement being exempted, but not necessarily.

57. The European Commission let unsolved the problem of solidary financing from collective media rights selling. In our opinion, if a federation uses the argument of the "sports specificity", but before it concluded agreements for more than three years, which obviously foreclose the market and impede potential competitors to enter the market, it is a sign that the agreement falls under Art. 101(1) TFEU. To apply the exemption from Article 101(3) TFEU, it is necessary to exist a benefit for the consumer and for the market. In Champions League case did not exist.

The problem of solidarity in sports is still unsolved. It is unacceptable to sacrifice the consumer welfare when actually there is no solidarity, but rather a commercial activity trying to escape the competition law.

58. We must admit that sports media rights selling appear interesting both from the economic and legal points of view. It is an important source of revenue for the sector. But nevertheless, it is an economic activity performed by undertakings on a specific market which produces effects not only for sports entities or media companies, but also for consumers, other suppliers and the market itself.

As we demonstrated above each of the Article 101(1) TFEU conditions are applicable to sports media rights selling. Antitrust law comes in scene when such an agreement is concluded. This selling appears both as collective and exclusive which may create the appearance of breaking competition law rules. But both the European Commission and ECJ demonstrated how first impression shall not mislead the investigation. Each case has to be treated individually.

\section{Sports sponsorship agreements under competition law provisions}

59. Sponsorship represents another very used source to finance the sports sector.

"Sponsorship is a commercial agreement between the sponsor, usually a private company, which pays a certain sum of money (sponsorship fee) and/ or provides certain products, services or other facilities to the Rights Holders, in return for which the sponsor is 
granted certain rights of association with the Rights Holders, through which the sponsor can promote its image and sale of its products and/or services ${ }^{56}$ ".

60. In sports, off all marketing arrangements, sponsorships are considered the "bed rock". It is one of the most common ways for the companies to promote their products and services. For example, the brand PUMA signed a sponsorship contract with the athlete Usain Bolt for 20 million dollars, the tennis star, Maria Sharappova concluded sponsorship agreements with Nestle, Evian, Avon and Nike. But the most impressive sponsorship contracts have been reported as coming from the football sector ${ }^{57}$.

61. As it can be perceived, private companies decide to invest in sports in order to develop their international brand, their popularity and to attract new customers.

62. Competition law provisions interfere in sponsorship agreements when it appears that sponsors claim a sort of exclusivity. Having an exclusivity is not always against competition law and not always harmful for the market. This was the opinion of the French Competition Council in 1997 in Adidas case ${ }^{58}$. But some previous conditions must have been fulfilled before this exclusivity was acquired. One of these conditions is existence of previous tender offers and a selection according to objective criteria. The French Competition Council decided that this agreement of exclusive sponsorship for a period of five years signed between the National Football League and Adidas was against the French equivalent of Art. 101(1). This decision was upheld by the Paris Court of Appeal.

The French Competition Council maintained its position in a similar case regarding a sponsorship agreement concluded between the French Sport Federation and its balls' producers $^{59}$ - no tender offers before the conclusion of the contract it harms the competition and such a behaviour falls within the scope of the correspondent of Art.101 (1) TFEU.

63. If a national federation obliges the clubs or the individual athletes buy or use exclusively only one type of product because the federation concluded a sponsorship contract with a private company, there is an abuse of dominance from the federation: including an obligatory clause to have only the insurance provided by a specific company in order to have delivered the professional licence even if the price of this insurance will be reimbursed afterwards ${ }^{60}$ or the obligation to use only a certain type of sport equipment delivered by a specific company to the federation is against national and European antitrust law $^{61}$. The sponsorship agreement falls within the scope of Art.101(1) if a call of offers was not issued before the conclusion.

64. When a federation concludes exclusive sponsorship agreements for a period of 4 years and inserts in the contract a clause of tacit reconduction, this agreement falls within the scope of antitrust law. Moreover, the clause constitutes an artificial barrier for the competitors and forecloses the market ${ }^{62}$. 
65. The European Commission started its first investigation in a case regarding a sponsorship agreement concluded between the Danish Tennis Federation and its tennis ball suppliers ${ }^{63}$. The Danish Tennis Federation (DTF) had a system, since the eighties, by which it had the ability to conclude sponsorship agreements without any call for tender and by using only its internal selection criteria for the sponsors.

Obviously, there was a presumption that the DTF did not have any objective criteria. What is more, the contracts were concluded for an undetermined period and the players were obliged to use in competitions only the balls with the inscription "official ball" or "official supplier". The European Commission concluded that these agreements violated Art. 101(1) TFEU provisions. It allowed the DTF to modify its sponsorship agreements and internal rules regarding conclusion of sponsorship contracts.

When the Commission retook the investigation, DTF indeed modified its internal regulations and adopted a new system for sponsorship agreements' conclusion: DTF will call for tender every two years to choose a sponsor. The selection will be transparent, non-discriminatory and opened to all suppliers.

The selected sponsor will be granted the denomination "sponsor of the DTF" (but not "official") and will become the only tennis ball supplier for tournaments organised by the DTF during the two-year period. In exchange, it will supply a specified quantity of balls at a preferential price below the Danish market price ${ }^{64}$.

66. An interesting decision was issued by a Dutch Court. In November 2011, the District Court of Utrecht found that an exclusive sponsorship agreement signed by the Dutch Badminton Association (NBB) with a sponsor, Yonex, for a substantial sum of money do not fall within the scope of prohibition of cartels. But if the Federation obliges badminton professionals to terminate their private sponsorship agreements signed with other sponsors in order to sign with Yonex then the NBB abuses of its position. ${ }^{65}$ The Court concluded that a sponsor aims to sign a contract mainly if it has exclusivity, otherwise there is no incentive for sponsorship.

67. A recent survey conducted by the Organisation for Economic Cooperation and Development (OECD) indicated that a competition-law effect can only occur in the event of (a system of) special circumstances. This could include, for instance:

- an extremely long duration of the exclusive contract, as a result of which there can be no competition for the exclusive right;

- the scope of the contract (can the bound players or teams be sponsored by a competitor at other events);

- the possibilities of promoting competing products via other channels and/or sponsorship contracts (in addition to the exclusively bound players or teams, are there other events or players than the exclusively bound players available for sponsoring $)^{66}$. 


\section{examples \\ PART II. Article 102 TFEU applied in the sports field - Conditions and practical}

68. Articles 101 and 102 TFUE are the core of antitrust law. While Art. 101 prohibits a collaborative behaviour which may harm competition and the market, Art. 102 sanctions the unilateral behaviour coming from one big player or from a group of influential undertakings on the market which act in an abusive manner.

69. The conditions which have to be fulfilled in order to apply Art. 102 can be extracted from its text: (1) existence of one or more undertakings, (2) existence of a dominant position within the market or in a substantial part of it; (3) existence of an abuse such as: unfair purchase or selling prices; unfair trading conditions; limitation on the production, markets or technical development; application of dissimilar conditions to equivalent transactions with other trading parties by placing them at a competitive disadvantage; imposing supplementary obligations to the contracting parties which were not previewed before; (4) the commerce between Member States shall be affected by this behaviour.

70. The undertaking has dominance on the relevant market or in substantial part of it. The concept of "dominant position" was defined in United Brands ${ }^{67}$ case: "The dominant position thus referred to by Art. 102 relates to a position of economic strength enjoyed by an undertaking which enables it to prevent effective competition being maintained on the relevant market by affording it the power to behave to an appreciable extent independently of its competitors, customers and ultimately of its consumers".

The ECJ seeks to compare the market share of the actual undertakings on the relevant market. According to ECJ jurisprudence ${ }^{68}$ created in a case of reference for competition law, AZKO v Commission ${ }^{69}$, if an undertaking has a market share of $50 \%$ or more than $50 \%$ then it has a dominant position. Moreover, in United Brands, the Court stated that even if the market share is of 40 up to $45 \%$ there is also a dominant position for that undertaking. In Virgin $v$ British Airways ${ }^{70}$, the Court stated that a market share lower than $40 \%$ indicates a dominant position but because the rivals had very low market shares.

71. Regarding the concept of "a substantial part of the market" the European Court concluded that each case shall be treated according to its specificities. Sometimes the test of substantiality may be negative regarding the Internal Market, but in other cases even the market of only one Member State may be sufficient to prove the dominance.

72. The concept of abuse was defined by the ECJ. Also, the European legislator gave some examples of what may be an abusive behaviour on the market. But the list provided in Art. 102 TFEU is not an exhaustive one.

73. There is no sanction for the existence of dominance of an undertaking or a group of undertakings on a specific market. The abuse of this position is punished if the dominant undertaking uses its position in such a manner which harms the competition and finally the consumers. So, those undertakings which have acquired dominant position shall have to respect many obligations ${ }^{71}$ 
74. In the field of sports, dominance is worldwide accepted. Every sports area needs a federation to adopt the so-called "game rules", so they have a regulatory monopoly. But there are rules which do not comply with competition law. This type of provisions is attentively observed by the competition regulators. Such non-compliance cases can be seen in the field of competition organizing rules or commercialisation of sports activities.

\section{Dominance in sport law? Practical examples for Article 102 TFEU}

Power can corrupt the human being and absolute power creates absolute corruption ${ }^{72}$.

75. In sports, some entities might acquire dominant position. On one hand it can be the individual athlete, the sports teams or sports clubs. On the other hand dominance can come from the federations. A special situation appears in case of private companies acting in the sports business: companies producing sport equipment, supplements or even media companies.

\section{A. Entities which may have dominance in sport sector (i). Athletes, sport teams and sport clubs}

76. A dominant position refers to "a position of economic strength enjoyed by an undertaking which enables it to prevent effective competition being maintained on the relevant market by affording it the power to behave to an appreciable extent independently of its competitors, customers and ultimately of its consumers ${ }^{73 \prime \prime}$.

77. The idea that individual sportsmen, teams or sports clubs can have a dominant position on the market was firstly analysed by the General Advocate Lenz in Bosman case $^{74}$. Each of these three entities is an undertaking when has an economic activity.

On a specific market one or more undertakings can be dominant and their unilateral behaviour can hinder competition. But sports competition itself is a specific issue due to the numerous players on the market whether is about individual sports like judo, tennis, boxing, karate etc. or sports teams. Like clubs and teams, they rely on their competitors in order to exist on the market.

78. Regarding the assumption that sportsmen can acquire a dominant position, we think this might happen in a sport not very practiced. But to consider that an individual sportsman having a dominant position on the market will try making an abuse of it that scarcely is possible. The same assumption is relevant for teams and clubs.

79. As AG Lenz stated in his conclusions for the Bosman case there can be considered a situation of dominance like a collective dominance ${ }^{75}$ of sports clubs derived from the fact that the sports clubs from a professional division are united by an economic reason ${ }^{76}$. Each club has a double interest: firstly, its own prosperity and secondly, prosperity of its competitors. 
80. Mr Lenz proposed a situation when this collective dominance may affect the market and the consumers: when clubs regroup to discuss selling of broadcasting rights. For example in case of football, a group of 14 of the biggest European football clubs created a group to negotiate with UEFA the selling of media rights for European competitions. This "Europe Club" negotiates television rights for the participation at the European competitions. In such a case, it might be possible to see Art. 102 TFEU applied ${ }^{77}$.

Otherwise, cases when an individual sportsmen/team or club can achieve dominance are highly impossible to see, due to the specificity of sports.

81. A situation of collective dominance can be imagined. For example, in the case of an individual sportsman when he refuses to play in a competition or to promote a product or to honour their obligations in a sponsorship contract or if he can decide who will acquire the television rights. But even if it happens, our assumption is that civil liability for non-performance applies better.

\section{(ii). Dominance of sport federations}

82. Sports federations have a de jure monopoly regarding organisation of sports both at national and European level. The same is the situation at the International level.

83. There is no debate that every sport needs a regulatory body to adopt the so called "game rules". In this matter, European law shall not interfere. But European law cannot allow sports regulators to adopt rules which may have a negative effect on the Internal Market. These bodies act in a double quality: pure sports regulators and economic regulators.

The European Commission had an attempt to make a distinction between "purely sporting activities", which shall fall outside the scope of Art. 101 and 102 TFEU, and the economic activities in this field, which are subject to antitrust law ${ }^{78}$. But in the ruling in Meca-Media ${ }^{79}$ (2006) the ECJ dismissed the concept of "purely sporting exception:": "It is apparent that the mere fact that a rule is purely sporting in nature does not have the effect of removing from the scope of the Treaty the person engaging in the activity governed by that rule or the body which has laid it down.

After this decision, it became crystal clear that regulatory aspects of sports must comply with the requirements of both Art. 101 and 102 TFEU. In par. 42 of the decision the Court applied the rules of Wouters method tin order do test of proportionality: "as long as an organisational sporting rule is inherent and proportional to a legitimate objective in the interest of sports, its restrictive effects are not caught by the prohibitions of Article 101(1) TFEU and 102 TFEU".

So, after Meca-Medina it is accepted that a sports federation is an undertaking which can adopt decisions, rules with or without an economic effect, but which can be subject to antitrust law.

84. A federation can have dominance on a specific market like selling of tickets, selling of television rights, conclusion of sponsorship agreements. The idea of analysing the market was also expressed by the AG in Bosman case: "It must therefore first be 
ascertained whether it is the clubs or their associations which must be considered in the present connection. Since the rules in question are contained in the regulations of the various associations, the obvious approach would in itself be to look at their position on the market. If, for example, the present case concerned the question of the marketing of television rights for the UEFA Champions League, one would plainly have to consider the market position of UEFA, which organizes and markets that competition."'(par.282)

Also in Meca-Medica, the ECJ highlighted the monopoly that the federation has regarding the regulatory and why this regulatory falls within the scope of Art. 102. In Deliège case, the European judge stated that the Belgian Judo Federation had dominance regarding the organisation of Belgian market on judo competitions.

85. It must be taken into account that dominance equals with the concentration of economic power to only one or few undertakings. Being in dominance, the powerful undertaking has the capacity to change the market as it wishes, to impose its conditions, objectives to its clients, competitors and finally to consumers ${ }^{80}$.

In Bosman, the General Advocate concluded that there certainly exists a dominance of the national federations, one of the European federations (UEFA for football) and also a collective one when few clubs regroup themselves in some specific situations. But Mr Lenz let the question opened if we have to consider UEFA as an association of undertakings or there is the possibility to see it as only one undertaking which acts unilaterally and not as an expression of its members' will.

86. If it are taken into consideration the case law until this moment and the Statutes of UEFA (plus of some national federations not only in football, but also in other sports) the conclusion is that these entities have a double character: single and influential undertaking, but also as an association of undertakings. In some areas, such as selling of television rights or tickets they cease to represent the clubs. Now they act as an independent body.

Even if they claim to represent clubs' interests, these federations have dominance on the market of broadcasting. Clubs are not allowed to interfere in the contracts concluded by the European and/or national federations. These federations are in a position of power and they can influence the market.

87. The European Commission sanctioned, in 1998, the French Organizing Committee of the World Football Cup because of abuse of dominance regarding the ticket selling. It creates some extra advantages for French buyers.

Again in 2006, the European Commission demanded that in the second phase of tickets selling there should be allowed buying also without credit card or via an internet banking purchasing from a bank account from the organising country. The Commission demanded that the buyers shall be allowed to pay with their own national bank accounts via an electronic transfer from their national coin.

The same situation regarding the possibility to purchase online the ticket and pay it by using a national bank account happened in 2004 with the Organizing Committee of the Athens' Olympiad. The organizers had to comfort with the Commission's requirement. 
88. The General Court, considered that FIFA has a position of collective dominance regarding the rules of player's agents ${ }^{81}$ because it is actually the clubs' decision which is adopted by the intermediary, in this case FIFA.

89. In our opinion, this dominance whether exists as singular or collective because sports clubs associated themselves can still be argued. But nevertheless, no matter how we call it there is a proof that national, European and international federations have a dominant position regarding sports regulatory. This conducts to the other consequence that antitrust law is applicable. Moreover since Meca Medina even what can appear as a purely sporting rule may actually affect the competition falling within the scope of Art. 101 and 102 TFEU.

90. Abuse of dominance exists also when the national federations oblige clubs or individual athletes to buy or use exclusively one type of product because the federation concluded a sponsorship contract with a private company: including an obligatory clause to have only the insurance provided by a specific company in order to have delivered the professional licence, even if the price of this insurance will be reimbursed afterwards ${ }^{82}$ or the obligation to use only a certain type of sport equipment delivered by a specific company to the federation, it is against national and European antitrust law ${ }^{83}$.

We will go further to analyse how private companies can acquire dominance in the sports industry and how their behaviour can affect sports competitions, clubs, athletes and finally, the consumers.

\section{Private companies, dominance and abuse of dominance in sport business}

91. Sports used to be a sector of public interest. Little by little it developed as a business and private companies started to become more and more active. These private companies can be equipment or supplements producers, media companies or any other company which deliver a service or a product useful in a manner in the sport sector, as it was seen above event insurance companies can deliver a product useful for an athlete.

92. The most common cases with private companies acting in sport services which were investigated by the European Commission concerned media rights selling, sports goods and state aids when private companies were selected as tenders.

Regarding media rights selling cases, these were investigated under Art. 101 (1) TFEU because in every case were agreements concluded between undertakings not a unilateral behaviour of an undertaking.

93. The European Commission investigated some cases which seemed to be break Art.102. But in two of them, VEGA Spa/ CIK-FIA ${ }^{84}$ and FIFA-Technical specifications of footballs ${ }^{85}$, the Commission concluded that Art.102 does not apply because in none of them it was dominance either of the sport federation, or of a private company. 
On the other hand, in Danish Tennis Federation $\operatorname{case}^{86}$, on its first investigation the European Commission concluded that allowing the Danish Tennis Federation to nominate the sponsors of tennis ball suppliers on an exclusive and unilateral manner and giving the permission to write on the balls "official supplier/ official ball" revealed of a conduct falling in the scope of Art. 102. In this situation it can be observed two undertakings in dominance: the DTF and the official supplier which by an agreement with the DTF acquired dominance on the market of tennis balls. After the first investigation of the European Commission, the DTF changed its policy in order to comply with Art. 102.

94. It is interesting to see that private companies acquire a dominant position in a sports related market because another undertaking, a sports federation. There is a causerelation effect: a dominant undertaking empowers another one to become dominant as well. Such a situation is dangerous and competition authorities sanction it every time. Private companies shall interfere in sports related markets in order to help athletes, teams and clubs, not only to seek the economic advantages.

\section{Conclusions}

96. After December 2009, it was for the first time when the European Union inserted in a Treaty provisions related to sport. Until then, European law applied in some cases when sports had an economic dimension. But since 2009 not only when is seen as an economic activity. In this paper our goal was to offer a short glimpse on this new business sector.

97. Since 1995, after the European Court's ruling in Bosman, the sports sector passed through a process of total transformation.

At the European level, competition rules encompass the antitrust and state aid regulations. This first part of our research was concentrated more on the application of Art. 101 and 102 TFEU in the sports sector. Antitrust law applies in the same conditions with a difference when it comes to sports specificity. This concept may lead to the conclusion that sports activities are not economic ones. As the ECJ stated four decades ago, if there is a profit making activity/lucrative/economic one in sports, then the European law provisions shall be enforced.

98. The European Commission conducted some investigations under both Art. 101 and 102 TFEU. In sports, there exist undertakings and associations of undertakings which comply with the definition offered by the European case law. These entities may try to distort competition on the internal market. It does not matter if the undertaking is an athlete, a sport club, association or a federation, when they perform economic activities, they have a duty to comply with European Competition Law.

Art. 101 TFEU applies, mainly when sports clubs conclude financing contracts with different private companies, mostly media trusts. A media right selling represents the consequence of the sport commercialization. It is an activity which brings profit to those 
involved in the media agreements. This led the European Commission to start investigations when media rights were selectively and exclusively sold only to some broadcasters. Such a selling is covered by Art. 101 (1) TFEU.

Apparently, even if these rights have an economic aspect because they are related to a special field, such as the sports, and with regulatory bodies sustaining its specificity, some difficulties may appear. But nevertheless media rights selling in sports shall be seen as an economic activity which has to comply with EU law.

99. Another manner to finance sports is represented by the conclusion of sponsorship agreements. Such contracts bring to our attention interesting legal issues. One of them touches competition law. Sponsorship contracts can be negotiated and signed with athletes, clubs or even federations. If a club or an athlete signs a contract for a longer period of time there is no point to consider is against competition law provisions. In the cases where the sponsorship contract was signed by a sport federation then a period longer than 2 years can lead to a foreclosure of the market which is against antitrust law and falls within the scope of Article 101(1) TFEU.

These contracts do not harm competition because out there is a big market of athletes. But they may distort the competition when an entity having decisional power can create the milieu for a sponsor to became dominant or if obliges clubs or athletes to sign with that particular sponsor. In these situations, EU antitrust law applies.

100. In Part II of this article we tried to see if Art. 102 TFEU can also be applied in the sports sector. As it was said many times, the Treaties do not sanction the existence of dominance, but the abuse of it. Those who acquired dominance, no matter how, have a special obligation to not use this power in a way that can harm the market.

In the sports field, dominance existed ever since because in most of the cases there is only one federation as a regulatory body. Also in concluding sponsorship contracts for a competition or in selling of media rights if they own those rights, sport federations may be the only ones able to sing those contracts. And this is the mechanism used by sponsors in order to win a contract for a very long period of time.

This is the moment when Art. 102 TFEU comes in place because an undertaking or an association of undertakings had a unilateral behaviour (signed a contract) and foreclosed a specific market related with the sport by using its power as a representative of the clubs. The effect was that another undertaking, which is a private one, acquired a dominant position on a market related to sport.

So, dominance in sport, in our opinion, shall be viewed as a two level construction: a dominance coming from the sports regulatory bodies and one for the private companies acting in the sports business. Both fall under Art. 102 TFEU's provisions as the ECJ case law proved it in Meca Medina or Deliège cases.

\footnotetext{
${ }^{1}$ The opinions and views expressed in this article are only personal consideration.

*ghicajanu_daniela@yahoo.com.

${ }^{2}$ ECJ, Decision from 14th of 1976, Case C-13/76, Dona / Montero, Rec. 1976, p.1333
} 
${ }^{3}$ ECJ, Decision from 12th of 1974, Case C-36/74, BNO Wlarave and Koch vs. Union Cycliste Internationale and others., Rec. 1974, p.1405

${ }^{4}$ CJCE, Decision from $15^{\text {th }}$ of December 1995, Case C-415/93 Union Royale Belge des Sociétés de Football Association ASBL and others/ Jean-Marc Bosman and others, [1995], ECR, p. I-4921

${ }^{5}$ Only in 2004 the sport's revenues were around $€ 407$ billion representing $3.7 \%$ of EU GDP. For more

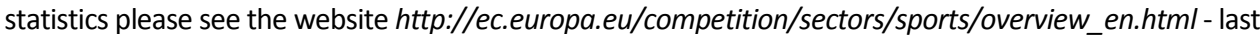
consulted in 17th of July 2016 last seen on $10^{\text {th }}$ of August 2016

${ }^{6}$ CA Paris, Decision from $23^{\text {rd }}$ of December 1991, La Cinq S.A, BOCC 1992, no. 3, p.42 - In this Decision the Appellate Court of Paris ruled that the cessation of broadcasting rights for sport events is a services activity. Thus, competition law applies.

${ }^{7}$ EU Council Declaration- Annexe to Nice Treaty: "It is fundamental to take into account in each action of the European Community the social, educational and cultural functions of sport which express its specificity with the aim to respect and promote ethics and the necessary solidarities to preserve its social role."

${ }^{8}$ F. Berthault, Le droit de la concurrence appliqué au secteur sportif, Legicom no. 3, 2000, pp. 47-60; J.F Pons, Le sport et la politique européenne de la concurrence : règles du jeu et exemples récents, in L'Europe et le sport, published by l'Institut de Relations Internationales et Stratégiques ; B. Geneste, Les fédérations sportives face au droit de la concurrence, RAE, 1999, p. 147 ; L. Idot, Sport et concurrence, Rev. Conc. Conso., 1999, p.6 ; K. Van Miert, Sport et concurrence: développements récents et action de la Commission, RMUE, 1997, no. 4 ; G. Campogrande, Les règles de concurrence et les entreprises sportives professionnelles après l'arrêt Bosman, RMUE, 1996, no. 1 ; D. Primault, Concurrence sportive et concurrence économique sont-elles compatibles ?, Rev. Conc. Conso., 1999, p.11 ; G. Auneau et P. Jacq, L'application du droit de la concurrence aux pratiques sportives, Rev. jurisp. Co., 1995, p. 371 et 1996, p. 24 ; G. Auneau, Les conséquences de l'application du droit de la concurrence au secteur du sport, Rev. jurisp. Co., 1998, p. 157 ; Dict. Permanent Droit du sport, Droit de la concurrence et sport, 2000

${ }^{9}$ CJCE, Decision from $18^{\text {th }}$ of July 2006, Case C-519/04, David Meca Medina and Igor Majcen v. Commission, [2006] ECR p-I 6991

10 This was UEFA's argument in Bosman case saying that transfer rules are part of the sport's exception and cannot be submitted to EU law.

${ }^{11} \mathrm{~L}$. Idot, Sport et concurrence, previous article.; J F. Gunther, La gestion des droits de radiodiffusion, Rev. conc. Consomm., 1999, no. 111, p. 20

12 Full text of Article 101 TFEU:"1. The following shall be prohibited as incompatible with the internal market: all agreements between undertakings, decisions by associations of undertakings and concerted practices which may affect trade between Member States and which have as their object or effect the prevention, restriction or distortion of competition within the internal market, and in particular those which: (a) directly or indirectly fi x purchase or selling prices or any other trading conditions; (b) limit or control production, markets, technical development, or investment; (c) share markets or sources of supply;(d) apply dissimilar conditions to equivalent transactions with other trading parties, thereby placing them at a competitive disadvantage; (e) make the conclusion of contracts subject to the acceptance by other parties of supplementary obligations which, by their nature or according to commercial usage, have no connection with the subject of such contracts. 2. Any agreements or decisions prohibited pursuant to this Article shall be automatically void. 3. The provisions of paragraph 1 may, however, be declared inapplicable in the case of:

- any agreement or category of agreements between undertakings;

- any decision or category of decisions by associations of undertakings;

- any concerted practice or category of concerted practices; 
which contributes to improving the production or distribution of goods or to promoting technical or economic progress, while allowing consumers a fair share of the resulting benefit, and which does not: (a) impose on the undertakings concerned restrictions which are not indispensable to the attainment of these objectives; (b) afford such undertakings the possibility of eliminating competition in respect of a substantial part of the products in question. "

${ }^{13}$ CJCE, Decision from 23th of April 1991, Case C-41/90, Hofner and Elser v Macrotron GmbH, [1991] ECR I- 1979, CJCE, Decision from 17th of February 1993, Case C-159/91 et C-160/91, Christian Poucet c/ Assurances générales de France et Caisse mutuelle régionale du Languedoc-Roussillon, [1993] ECR, p. I-637

${ }^{14}$ CJCE, Decision from 23th of April 1991, Case C-41/90, Hofner and Elser v Macrotron GmbH, [1991] ECR I- 1979,

${ }^{15}$ CJCE, Decision from $19^{\text {th }}$ of February 2002, Case C- 309/99, Wouters and others [2002] ECR I- 1577

${ }^{16}$ In case of an amateur is little chance that he performs an economic activity for the club. Maybe the club or the association has such an activity. But in the case of professional sportsmen the CJEU stated very clear that when they receive a salary, as part of team, or remuneration for their services (image, publicity contracts, and sponsorships) then they perform an economic activity- Dona ruling. In Bosman, according to the Advocate General's opinion even the athletes' part of a team can be considered as undertakings.

${ }^{17} \mathrm{CFI}$, Decision from $9^{\text {th }}$ of November 1994, Case T-46/92, , Scottish Football Association /Commission, [1994] ECR, p. II-01039: "activities like concluding publicity contracts, use of World Cup emblems and broadcasting or TV retransmission of sport events are economic activities within the meaning of the European law and this court case law"

${ }^{18}$ EC, Decision 92/521 from $27^{\text {th }}$ of October 1990, Case COMP/33.384 and 33.378, FIFA World Cup 1990 (Italy)

${ }^{19}$ EC, Decision from 20 th of July 1999, Case COMP/36.888, PO/World Cup 1998 (France)

${ }^{20}$ L. Idot, op. cit. p.7; G. Auneau, La notion d'entreprise sportive en droit français et en droit communautaire, Rev. jurisp. Co., 1994, p. 141; M. Thill, La reconnaissance de la spécificité du sport en droit communautaire, Europe, June 2000, p. 4.

${ }^{21}$ CJCE, Decision from 11th of April 2000, Joint Cases C 51/96 et C 191/97, Deliège v Ligue de Judo, [2000] ECR I-254911. In this ruling the opinion of the General Attorney deserves to be taken into account because it pointed out that "practicing an amateur sport but at an elevated level can be considered also as an economic activity"; N. Parisis et M. F. Salas, Le sportif individuel au regard de l'arrêt Bosman : les ordonnances Deliège, RMUE, 1996, no 1.

${ }^{22}$ Commission Notice par. 7 and 8: "A relevant product market comprises all those products and/or services which are regarded as interchangeable or substitutable by the consumer, by the reason of the products' characteristics, their prices and their intended use. The relevant geographic market comprises the area in which the undertakings concerned are involved in the supply and demand of products and services, in which the conditions of competition are sufficiently homogeneous and which can be distinguished from neighbouring areas because the conditions of competition are appreciably different in those areas".

${ }^{23}$ F. Rizzo, Le droit de la concurrence au service de la specifité sportive, Chronique de droit de la concurrence, http://www.revuegeneraledudroit.eu/wp-content/uploads/aj20011219rizzof1.pdf last consulted on 17th of July.

${ }^{24}$ A. Pappalardo and N. Parisis, Le droit de la concurrence et le sport professionnel par équipe : quelques appréciations critiques sur la notion de marché en cause, en marge de l'affaire Bosman, RMUE, 1996, no. 1 
25 This is the materialisation of a concerted practice. But we shall pay attention to the fact that not every contract is prohibited just those with an anti-competitive effect on the market. In sport, contracts are concluded regarding the commercialisation of sport activities (selling of tickets or selling the media rights) and the financing of sport activities via a sponsorship contract. This is principle application of Article 101(1) TFUE.

${ }^{26}$ EC, Decision from 14th of August 1990, Case no. 33-249 La Cinq SA c/ UER, Court of First Instance, Decision from 24 $4^{\text {th }}$ of January 1992, Case T-44/90, La Cinq SA / Commission of the European Community, RJCE, II, p.1

${ }^{27} \mathrm{M}$. Sabatier, Droit de la concurrence et compétition sportive, https://cdcmmontpellier.files.wordpress.com/2015/01/m-sabatier-droit-de-la-concurrence-etcompc3a9tition-sportive-1.pdf last consulted on 18th of July 2016

${ }^{28}$ Court of First Instance, Decision from $24^{\text {th }}$ of January 1992, Case T-44/90 La Cinq SA c/ Commission des Communautés Européennes, RJCE, II, p.1

${ }^{29}$ CJUE, Decision from $6^{\text {th }}$ of October 2009, Case C-501/06, GlaxoSmithKline Services Unlimited v. Commission, [2009] ECR I - 9291, point 58

${ }^{30}$ CJCE, Decision from $4^{\text {th }}$ of June 2009, Case C- 8/08, T- Mobile Netherlands [2009] ECR I - 4529

${ }^{31}$ CJCE, Decision from $19^{\text {th }}$ of February 2002, Case C - 309/99, Wouters v Algemene Raad van de Nederlandsche Orde van Advocaten, [2002] ECR I - 1577

32 CJCE, Decision from $18^{\text {th }}$ of July 2006, Case C-519/04P, David Meca Medina and Igor Majcen v. Commission.

${ }^{33}$ K. Lefever, New Media and Sport. International Legal Aspects, Asser International Sports Law Series, TMC Asser Press, Springer, The Hague, The Netherlands, 2012, p. 7

${ }^{34} \mathrm{~A}$ sport federation or national league which have special competence to sign these conventions

${ }^{35} \mathrm{~S}$. Weatherill, European Sports Law. Collected Papers, $2^{\text {nd }}$ Edition, Asser International Law Series, TMC Asser Press, Springer, The Hague, The Netherlands, 2014, p. 335

${ }^{36} \mathrm{EC}$, Decision from $20^{\text {th }}$ of July 1999, Case COMP/36.888, PO/World Cup 1998- discriminatory ticketing practices, published in OJ 2000 L 5/55; EC, Several decisions, Case COMP/ 38.173, The Football Association Premier League Limited, - joint selling of media rights; EC, Decision from $19^{\text {th }}$ of January 2005, Case COMP/ 37.214 The German Bundesliga joint selling of media rights; EC, Decision from $20^{\text {th }}$ of July 2001, Case COMP/ 37.398 UEFA Champions League- joint selling of media rights; EC, Case COMP/ 37.576 UEFA broadcasting regulations; EC, Case IV/ 32.150 EBU/ Eurovision- joint acquisition and exchange of sport media rights.

${ }^{37} \mathrm{CJCE}$, Case C-41/90, Höfner and Elser v Macrotron $\mathrm{GmbH}$,

${ }^{38}$ EC, Case COMP/37.398, Decision UEFA Champions League, par. 109

${ }^{39}$ CFI, Case T-7/89, SA Hercules Chemicals NV v. Commission, [1991] ECR II-1711

${ }^{40} \mathrm{EC}$, Decision UEFA Champions League, cited above

${ }^{41} \mathrm{EC}$, Decision The Football Association Premier Ltd, cited above

42 Ibidem par, 31

${ }^{43} \mathrm{~K}$. Lefever, cited above, p. 111.

${ }^{44}$ Ibidem, p. 107

${ }^{45}$ EC, Case IV/M.993, Decision Bertelsmann/Kirck/Premier, published in OJ C 1439, par. 18.

${ }^{46}$ Ibidem

${ }^{47}$ EC, Case COMP/37.214, Decision German Bundesliga,

${ }^{48} \mathrm{EC}$, Bertelsmann case, cited above 
${ }^{49}$ EC, Decision UEFA Champions League, cited above, par. 59, 62-63; EC, Decision from $2^{\text {nd }}$ of April 2003, Case COMP/M. 2876, Newscorp/Telepiù, published in OJ L 110/73

${ }^{50}$ CFI, Case T-403/93 Eurovision, OJ 1993 L 179/23 granting exemption under (what is now) Art. 101(1) TFEU was annulled in Joined Cases T-528/93, T-542/93, T-543/93 and T-546/93 Métropole Télévision and Others v. Commission, [1996] ECR II-649; and the subsequent exemption granted by the Commission in Decision 400/2000 Eurovision, OJ 2000 L 151/18 was annulled in Cases T-185/00 et al. $M 6$ and others v. Commission, [2002] ECR II-3805

${ }^{51}$ ECJ, Decision from $8^{\text {th }}$ of June 1982, Case C-258/78, Nungesser v Commission, [1982], ECR 2015

52 DG COMP-, Broadcasting of Sports Events and Competition Law, Wachtmeister 1998

${ }^{53} \mathrm{EC}$, Champions League, case cited above

${ }^{54} \mathrm{EC}$, Decision from $30^{\text {th }}$ of October 2001, Case COMP/ 35.163 FIA (Formula One), OJ 2001 C 169/5

${ }^{55} \mathrm{EC}$, Champions League Case, cited above

56 I.S.Blackshaw, Sports Marketing Agreements: Legal, Fiscal and Practical Aspects, TCM Asser Press, Springer, The Hagues, 2012, p. 125

57 In 2002, the football team Manchester United signed with Nike a contract for 13 years for over 302.9 million pounds; in 2013, Real Madrid concluded an agreement with Bwin for three years for 54.9 million pounds; in 2012, AC Milan and Fly Emirates singed a contract for a five year sponsorship for at least 52 million pounds

${ }^{58}$ French Competition Council, Decision from 7th of October 1997, Adidas case, BOCC 1987, no. 24

${ }^{59}$ F. Berthault, cited above., p. 30-31

${ }^{60}$ French State Council, Decision from 29th of September 2003, Figeac Athlétisme Club, Lebon 384

${ }^{61}$ French State Council, Decision from 19th of November 1997, Société Nike France and others, Lebon T. 1094; French State Council, Decision from 3rd of April 2006, Société Nike European Operations Netherlands BV and others, AJDA 2006. 1463

${ }^{62}$ French Competition Council, Decision from 13th of Mai 1998, Case 98-D-31, Fencing Sector; Revue Contrats Concurrence Consommation, 1198, no. 147

${ }^{63}$ EC, Decision from April 1998, Case COMP/ 33.055 and 35.759, Danish Tennis Federation

${ }^{64}$ Press release for the Danish Tennis Federation case, please see the website http://europa.eu/rapid/press-release_IP-98-355_en.htm?locale=en last seen on $21^{\text {st }}$ of July 2016

65 District Court of Utrecht, Decision from $30^{\text {th }}$ of November 2001, please see the website http://legalknowledgeportal.com/2012/01/02/exclusive-sponsorship-contract-not-in-violation-ofcompetition-law/, last visited on 21st of August 2016

${ }^{66}$ Ibidem

${ }^{67}$ CJCE, Case - 27/76, United Brands v Commission, [1978] ECR 207, [1978] 1 CMLR 429; par.65

${ }^{68}$ CFI, Case T - 51/89 Tetra Pak Rausing SA v Commission [1990] ECR II- 539, [1991] 4 CMLR 334; CJCE, Decision from $6^{\text {th }}$ of April 1995, Case C- 310/93 P BPB Industries Plc and British Gypsum Ltd v Commission [1995] ECR I- 865;

${ }^{69}$ CJCE, Case C - 62/86, AZKO v Commission [1991] ECR I- 3359

${ }^{70}$ CFI, Case T - 219/99 British Airways plc v Commission [2003] ECR II- 5917, par. 189-225, upheld on appeal to the Court of Justice, Case C- 95/04 P British Airways plc v Commission [2007] ECR I- 2331

${ }^{71}$ CJCE, Decision from $9^{\text {th }}$ of November 1983, Case 322/81, Michelin/Commission, [1983] ECR 3461

$72 \mathrm{Ch}$. De Secondat, baron de Montesquieu, About the Law Spirit, published by G. Bell\&Sons, Ltd., London, 1914

${ }^{73}$ ECJ, Case - 27/76 United Brands v Commission, [1978] ECR 207, [1978] 
${ }^{74}$ Conclusions of AG Lenz for Case C-415/93 published in JO I-4930-5039

${ }^{75} \mathrm{CFI}$, Case T-68/89 SIV v Commission, [1992] ECR, p. II-1403

${ }^{76}$ Opinion of Advocate General Mr Lenz, cited above.

77 M. Sabatier, op. cit., p. 51-52

78 B. Van Rompuy, cited above., p. 2; Commission Preliminary guidelines on the application of the competition rules to sport (internal memo to the Commission), SEC (1999) 249; Commission Report from the Commission to the European Council with a view to safeguarding current sports structures and maintaining the social function of sport within the Community framework - The Helsinki Report on Sport, COM (1999) 644 final; Commission, 'Commission debates application of its competition rules to sports', 24 February 1999, Press Release IP/99/133; Commission, 'Limits to the application of Treaty competition rules to sport: Commission gives clear signal', 9 December 1999, Press release IP/99/965.

${ }^{79}$ CJCE, Case C-519/04 David Meca-Medina and Igor Majcen v. Commission, par. 27

${ }^{80}$ M. Sabatier, cited above, p. 50

${ }^{81}$ CFI, Case T-193/02 Piau v Commision, [2005], ECR 2006 I-00037

82 French State Council, Decision from 29th of September 2003, Figeac Athlétisme Club, Lebon 384

${ }^{83}$ French State Council, Decision from 19th of November 1997, Société Nike France et autres, Lebon T. 1094; French State Council, Decision from 3rd of April 2006, Société Nike European Operations Nederlands BV et autre, AJDA 2006, no. 1463

${ }^{84}$ EC, Decision from $19^{\text {th }}$ of March 2004, Case COMP/38.316 VEGA Spa/ CIK-FIA, , OJ $13^{\text {th }}$ to $21^{\text {st }}$ of February 1962, p. 204

${ }^{85} \mathrm{EC}$, Decision from $1^{\text {st }}$ of March 2000, Case COMP/35.266 FIFA, http://ec.europa.eu/competition/elojade/isef/case_details.cfm?proc_code=1_35266

${ }^{86} \mathrm{EC}$, Danish Federation, cited above 